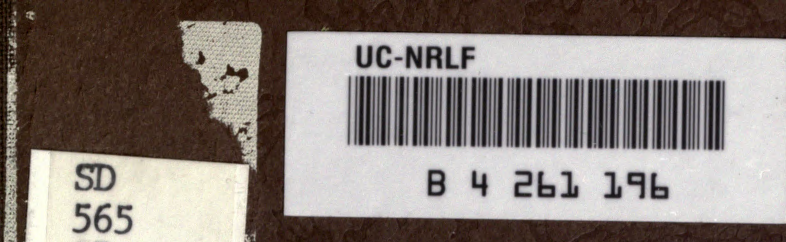

A5

1909

DOCS 



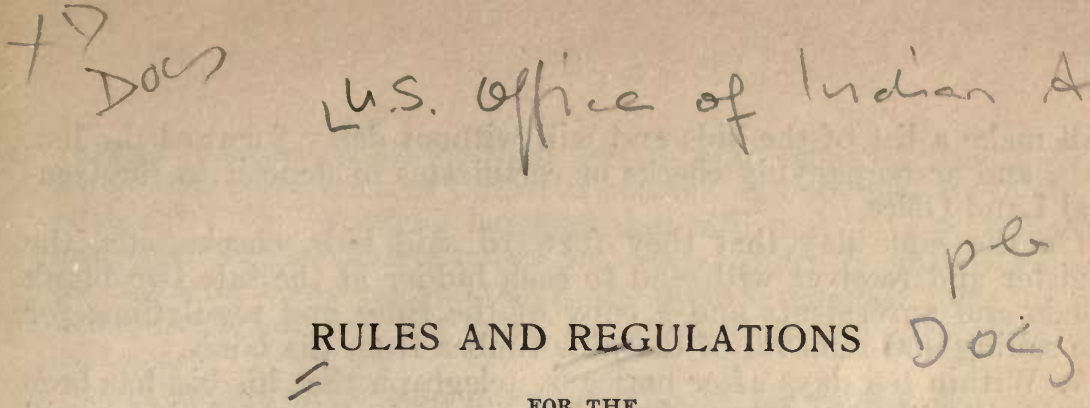

FOR THE

\section{Sale and Removal of Water-Killed and Windfall Timber on Chippewa Indian Ceded "Pine" Lands, Minnesota.}

\section{DepartMent OF THE INTERIOR, General Land Office,}

Washington, D. C., November 16, 1909.

1. The merchantable water-killed and windfall pine timber on the lands described in the accompanying descriptive list of ceded Chippewa lands in the State of Minnesota will be offered for sale, under sealed bids, under the fifth section of the act of January 14, 1889 (25 Stat. L., 642), as amended by the act of June 27, 1902 (32 Stat. L., 400). (See copy herewith.)

Said descriptive list gives the quantity of such timber reported by the examiners as having been found on each legal subdivision.

2. Bids for said timber will be opened at the district land office at Cass Lake, Minn., commencing at 9 o'clock a. m. on March 15, 1910. In order to receive consideration all bids must be filed in said district land office before 4 o'clock p. m. of the day preceding that fixed for the opening of bids. The bids shall be in accordance with forms furnished said district land office.

The right is reserved to reject any or all bids.

3. No bid will be received for a sum less than at the rate of $\$ 4$ per 1,000 feet for Norway pine and $\$ 5$ per 1,000 feet for white pine.

4. Bids may be for the timber on any separate section, or on groups of contiguous sections of land, and bids for timber on groups of sections may be in addition to bids for timber on separate sections.

5. Each bid shall be accompanied by cash or a certified check for 20 per cent of the amount of such bid, according to the value of the timber, as per the government estimate, the same to be retained and at once credited as part payment of the purchase price for the timber included in such bid should the bid be accepted, but to be retained by the United States as a forfeit if the bid is accepted and the bond and agreement required by these rules and regulations are not furnished. In case cash accompanies a bid the receiver will deposit the same as a special fund in the nearest United States depository.

6 . The register and receiver will number the bids consecutively as they are received, beginning with No. 1 , noting on each bid the date and hour of its receipt.

On opening the bids the register and receiver will indorse on the inclosures the number of the bid and the name of the bidder. They 


\section{Do is 2}

will make a list of the bids and will without delay forward the list, bids, and accompanying checks or certificates of deposit to the General Land Office.

On the same day that they forward said bids, checks, etc., the register and receiver will send to each bidder at the sale two blank bonds and agreements and a copy of the rules and regulations for the selling and removal of the pine timber from the lands.

7. Within ten days after notice by telegraph that his bid has been accepted by the Secretary of the Interior each successful bidder will be required to enter into and file an agreement and bond on forms approved by the Secretary of the Interior, the penalty of the bond to be of an amount which shall be 50 per cent of the estimated value of the timber embraced in the bid and purchase. He may submit one agreement and bond for all the timber awarded him at the sale, the agreement and bond to sufficiently identify and describe all the land. The bond shall be conditioned for the payment for said timber and for the faithful performance of said agreement, and for the observance of these regulations. The agreement and bond may be acknowledged by the purchaser of the timber, and the bond by sureties, before any officer authorized to take the acknowledgment of deeds in the State or Territory where executed.

In case of individual sureties, the parties will be required to justify in accordance with the special rules in regard thereto provided by the department, and the sufficiency of such sureties must be certified by the United States judge or district attorney of the district where such sureties reside.

8. Upon the filing in their office of said agreement and bond, duly executed, the register and receiver will immediately forward them to the General Land Office for transmission to the Secretary of the Interior. The agreement and bond may also be filed in the General Land Office. Notice of approval of said agreement and bond by the Secretary of the Interior shall be wired to the purchasers by the General Land Office.

9. Written notice of intention to begin removal of timber must be given by the purchaser to the superintendent of logging, whose address is Cass Lake, Minn., at least ten days in advance.

10. The sale of the timber will be subject to the right of the State of Minnesota to make selection of swamp and overflowed lands under the act of March 12, 1860 (12 Stat., 3), which matter is now pending.

11. The superintendent of logging and his assistants shall supervise the cutting, scaling, and removal of the timber. It shall be their duty to see that the rules and regulations are fully complied with; to see that no timber other than pine is cut, except as is allowed by the Secretary, and that no logs are removed from the place where banked until paid for; to see that all tops and refuse are promptly and properly burned or removed to prevent fire; to see that Indian labor is employed where practicable; and to supervise and direct the labor of the scalers. The superintendent shall make monthly reports of the progress of such work, and of the time, habits, and competency of his assistants and of the scalers, and he and his assistants shall generally perform such services in and about the sale of the pine timber on said lands and the cutting of the same therefrom, and the care and protection of all timber on said lands as may be required of them by the said Secretary. 
12. The scalers shall see that, before being removed from the tract where cut, every stick of timber is marked on both ends by the logger with a "U. S." marking hammer, and also that it is bark marked; and such scalers shall number and scale, under Scribner's rules, in the $\log$ after being cut and before the same is removed from the place where banked all logs cut under the application and agreement under said act.

Said scalers shall keep in suitable books for reference a record of the marks, also a complete list of numbers of all $\operatorname{logs}$, with the scale of each $\log$ set opposite its number, said scale books to be open to the inspection of the check scaler or to any authorized government representative at all times.

13. All timber must be scaled on the banking ground, landing, or skidway, and before it is placed on cars or put into the water.

14. All trees shall be cut with a saw whenever practicable and as low down as practicable.

15. All merchantable water-killed or blown-down pine timber which is 6 inches or over at the small end shall be logged. Any such timber left in the woods shall be scaled under the direction of the superintendent of logging and paid for by the purchaser of the timber at double the regular stumpage rate. No tree shall be left lodged in process of felling.

16. So far as reasonable all branches of the logging operations shall keep pace with each other. In no instance will the brush piling or burning be allowed to fall behind the cutting and removing of logs. It is the duty of the superintendent and of his assistants under his directions to see that the cutting is, as far as practicable, on consolidated areas and is not distributed here and there over the entire tract.

17. All tops and litter from trees cut under these rules must be burned so as to be safe against fire, under the supervision of the forest supervisor of the Bureau of Forestry, and at such time as he shall select, but the burning of tops or other material larger than 8 inches in diameter, or of tops or litter not made by logging under these rules, will not be required. The piles must be compact and large enough to burn clean without repiling, and must not be so near young growth or standing green trees as to endanger either of them, and must be placed where there is least danger of the fire spreading.

18. Unnecessary damage to young growth or trees left for seed must be carefully avoided.

19. As few log roads as practicable shall be cut, nor shall they be made wider than is actually necessary.

20. In case of the failure of a purchaser to comply with the directions of the superintendent of logging and his assistants in the matter of the piling and the burning of the brush and débris, the superintendent of logging shall have the same properly piled and burned and charge the expense thereof to the purchaser of the timber in the next monthly scale bill, first, however, giving the purchaser written notice of his intention to pile and burn the brush and débris and allowing him ten days from the date of such notice to comply with his instructions.

21. All instructions and demands from the superintendent or his assistants to or upon the loggers or purchasers shall be made in writing, including the demand for payment to be made when due, as hereinafter provided for. Legible press copies of such instruc- 
tions and demands must be kept by such superintendent and assistants in books provided for that purpose.

22. The timber described in the schedule as being on secs. 23, 24, 25 , and 26, T. 143 N., R. 31 W., which includes only the down timber on said sections, must be removed prior to October 1, 1910, and the remaining timber prior to July 1, 1911. In the removal of the timber sold hereunder no standing timber shall be cut, except such as may be actually necessary in order to remove the down timber, and then only when approved by the forest supervisor of the Minnesota National Forest, whose decision shall be final in the matter.

23. The money for the timber cut and scaled during each month shall become due and payable in monthly installments at the end of such month, or oftener, in the discretion of the suparintendent of logging, and shall be paid before said logs are removed from the place where banked; provided that no payment will be required until the scale bills for the timber cut on any bid or contract exceed the amount deposited with such bid. The timber may, by permission of the Commissioner of the General Land Office, be removed before the actual payment of the money in all cases where such course is recommended by the superintendent of logging and is approved by the proper Indian agent. If not so paid when dne, or within thirty days thereafter, and after written demand from the superintendent of logging, the said contract and the money paid thereunder may be declared forfeited by the Secretary of the Interior, and the timber may be banked, shipped, and sold by the superintendent, under the direction of the Secretary of the Interior, and the deposit made at time of bid and the net proceeds, after deducting expenses of banking, shipping, and selling, applied to the amount due therefor from such purchaser or logger, and any excess shall be paid to him. If excess be due from the logger after such sale by the Secretary, he shall pay the same upon demand from the superintendent.

24. The scale bills must be approved by the superintendent of $\log$ ging and such approval confirmed by the superintendent of Leech Lake Agency, Onigum, Minn., after examination thereof and of the check scale, if any, and thereupon the superintendent of logging shall demand payment, and such payment must be made to said superintendent, Leech Lake Agency, who shall account therefor to the Commissioner of Indian Affairs, and also report the several amounts paid to the superintendent of logging and the Commissioner of the General Land Office.

25. The decision of the superintendent of logging shall be final in the execution of the foregoing rules.

26. The violation of any of these rules, if persisted in, shall be deemed a sufficient cause for annulling the contract and canceling the sale of the stumpage. In case of damages caused by such violation of the rules and annulment and cancellation of the contract and sale, demand for the amount thereof, after ascertainment and approval by the Secretary of the Interior, shall be made by the superintendent of logging, and the purchaser will be allowed thirty days from such notice within which to pay the amount due.

\section{Fred Dennett, Commissioner General Land Office.}

Approved November 16, 1909.

R. A. Ballinger, Secretary. 
[Public-No. 175.]

An Act To ameud an act entitled "An act for the relief and civilization of the Chippewa Indians in the State of Minnesota," approved January fourteenth, eighteen hundred and eighty-nine.

Be it enacted by the Senate and House of Representatives of the United States of America in Congress assembled, Sec. 2. That section five of said act be amended so as to read as follows:

"SEc. 5. That whenever, and as often as the survey, examination, and lists of one hundred thousand acres of said pine lands or of a less quantity, in the discretion of the Secretary of the Interior, have been made and approved, the Secretary of the Interior shall be, and he hereby is, authorized and directed to sell, under such rules and regulations as he may prescribe, and at such times and places as he may designate, to be scaled under Scribner's rules in the log after-being cut, all the merchantable pine timber, whether the same be green or dead, standing or fallen, now on such pine lands, with the exception of five per centum of said timber on certain reservations as hereinafter provided, to be paid for when the timber is cut, banked, and scaled in the manner herein provided for: Provided, That said pine timber shall be advertised for sale in Government sections or parts of sactions, and shall be sold only by separate sealed bids for the pine timber on each section, and the Secretary of the Interior shall reserve the right to reject any or all of said bids: Provided, That the Secretary of the Interior may also receive bids in groups of not exceeding ten sections in any one bid, which bids may be in addition to the separate bids by sections on the same lands. The parties bidding shall accompany each of said sealed bids with cash or certified check for twenty per centum of the amount of the bid for the pine timber on any particular section or groups, according to the highest value as shown by the Government estimate as hereinbefore provided for, and said cash or certified check shall be retained and credited as part payment of the purchase price should the bid be accepted, but should the bid be rejected said cash or certified check shall be immediately returned to the bidder: Provided further, That said timber shall not be sold at a price less than four dollars per thousand feet board measure for Norway pine and five dollars per thousand feet board measure for white pine: Provided further, That the Secretary of the Interior may increase said minimum price on portions of said timber as he may deem just and proper: Provided further, That said Secretary may, if he shall deem it best, permit the purchaser of the timber on any Government section or group to erect a mill of a capacity of not less than forty thousand feet board measure of lumber per day, and to manufacture thereat the timber on said Government sections or groups, said mill to be located on said section or group, or at such place in the immediate vicinity as may be designated by said Secretary; and the said Secretary is authorized to lease to such purchaser not exceeding three hundred and twenty acres of land for mill purposes, for any one purchase, at an annual rental to be fixed by the Secretary of the Interior, for a renewable term not exceeding ten years, said term to end, in any event, so soon as the timber purchased shall have been sawed and removed, said lease of land to be exclusive of the timber 
thereon, which timber shall be disposed of as herein provided for other timber: And provided further, That prior to any sale the Secretary of the Interior shall cause notices of said sale to be inserted once in each week, for four successive weeks, in one newspaper of general circulation published in each of the following cities, namely: Minneapolis. Saint Paul, Duluth, Winona, and Crookston, Minnesota ; Chicago, Illinois; Milwaukee, La Crosse, Ashland, Wausau, and Marinette, Wisconsin; Detroit, Saginaw, Menominee, and Bay City, Michigan; Philadelphia and Williamsport, Pennsylvania; Boston, Massachusetts; New Orleans, Louisiana; Saint Louis, Missouri; Albany, New York, and Dubuque, Davenport, and Burlington, Iowa, and in the following trade journals, to wit: The Northwestern Lumberman, of Chicago, Illinois, and the Mississippi Valley Lumberman, of Minneapolis, Minnesota, of the sale of said timber as herein provided to the highest bidder, with the right to reject any and all bids, the first publication of said notices to be at least six calendar months prior to said sale, said notices to state the time and place and the terms of such sale, and to contain a general description of the lands from which the timber is to be sold, and shall refer intending bidders to the printed lists to be obtained from the Commissioner of the General Land Office or register of the local land office, as provided in section four of this act. Said notices shall also state in what tracts or parcels the timber is to be sold: Provided, That one additional notice calling attention particularly to the date of the sale shall be published thirty days prior to the day fixed for the sale in the first advertisement: Provided further, That in cutting the timber on two hundred thousand acres of the pine lands, to be selected as soon as practicable by the Forester of the Department of Agriculture, with the approval of the Secretary of the Interior, on the following reservations, to wit, Chippewas of the Mississippi, Leech Lake, Cass Lake, and Winnebigoshish, which said lands so selected shall be known and hereinafter described as 'forestry lands,' the purchaser shall be required to leave standing five per centum of the pine timber thereon for the purpose of reforestation, as hereinafter provided, said five per centum to be selected and reserved in such manner and under such rules and regulations as may be prescribed by the Forester of the Department of Agriculture and approved by the Secretary of the Interior: Provided further, That there shall be reserved from sale or settlement the timber and land on the islands in Cass Lake and in Leech Lake, and not less than one hundred and sixty acres at the extremity of Sugar Point, on Leech Lake, and the peninsula known as Pine Point, on which the new Leech Lake Agency is now located, which peninsula approximates seven thousand acres, and in addition thereto ten sections in area on said reservations last aforesaid, to be selected by the Forester of the Department of Agriculture, with the approval of the Secretary of the Interior, in lots not less than three hundred and twenty acres each in contiguous areas, and nothing herein contained shall interfere with the allotments to the Indians heretofore and hereafter made. The islands in Cass and Leech lakes and the land reserved at Sugar Point and Pine Point Peninsula shall remain as Indian land under the control of the Department of the Interior.

"Each and every purchaser of timber hereunder shall be required and shall enter into an agreement to cut clean and remove all the merchantable pine timber, whether green or dead, standing or fallen, on 
each tract, subdivision, or lot covered by his purchase, except on the forestry lands as hereinbefore provided, within such time as the Secretary of the Interior may direct, and under such rules and regulations as he may prescribe, and to cut no timber other than pine, except such as may be absolutely necessary in the economical conduct of the logging operations, and to burn or remove a sufficient amount of the tops and refuse to prevent danger from fire to the timber left standing, under rules and regulations to be prescribed by the Secretary of the Interior, and, when practicable, to employ Indian labor in the cutting, handling, and manufacture of said timber. And each and every purchaser shall be required to give a bond in a sufficient penalty, to be approved by the Secretary of the Interior, for the faithful performance of said agreement and for the observance of the regulations of the Secretary of the Interior concerning the sale, cutting, and removal of such timber: Provided, That the Secretary of the Interior shall, upon application, furnish to any persons who may expect to bid, not more than ninety days prior to the date of the sale of any pine timber hereinbefore mentioned, a statement of the rules and regulations under which said pine timber shall be cut and the tops and refuse thereof burnt or removed, and of the time within which said timber must be removed.

"Before being removed from the tract from which they are cut, all logs cut hereunder shall be stamped and bark-marked by the logger and numbered and scaled by competent and experienced scalers, to be appointed by the Secretary of the Interior and paid such reasonable salaries as may be fixed by him. Said scalers shall keep in suitable books for reference a record of the marks; also a complete list of the numbers of all logs, with the scale of each log set opposite its number, said scale books to be open to the inspection of the check scaler or to any authorized Government representative at all times; and said logs shall be landed separately from all other logs, and the title to said logs shall remain in the United States for the benefit of the Indians; and said logs shall not be removed from the place of landing until the purchase price agreed upon shall be fully paid to such officer of the Indian Department as shall be designated by the Secretary of the Interior to account for and receive the same. And the Secretary of the Interior may, at the request of the chiefs of said bands or tribes of Chippewa Indians of the State of Minnesota interested in the said timber sales, appoint check scalers to verify and inspect the work of the Government scalers; the said check scalers to be designated by said chiefs and paid out of the funds of the Indians such reasonable compensation as may be fixed by the Secretary of the Interior.

"After the merchantable pine timber on any tract, subdivision, or lot shall have been removed, such tract, subdivision, or lot shall, except on the forestry lands aforesaid, for the purposes of this act, be classed and treated as agricultural lands, and shall be opened to homestead entry in accordance with the provisions of this act: Provided, That on the forestry lands aforesaid, as soon as the merchantable pine timber now thereon shall have been removed from any tract, subdivision, or lot, as herein provided, such tract, subdivision, or lot shall, without further act, resolution, or proclamation, forthwith become and be part of a forest reserve, the same as though set apart by proclamation of the President in accordance with the act of Congress approved March third, eighteen hundred and ninety-one, 
and subsequent laws amending and supplementing the same, and shall be managed and protected in accordance with their provisions and the rules and regulations made and to be made in furtherance thereof: And provided further, That on said forestry lands aforesaid said pine timber shall be cut clean, except as to the five per centum as hereinbefore provided, and removed under the supervision and direction of the Forester of the Department of Agriculture, in accordance with rules and regulations to be prescribed by him and approved by the Secretary of the Interior, and the said Forester shall have power at all times to patrol and protect said lands and forests, and to enforce all rules and regulations made by him as aforesaid.

"As soon as practicable after the passage of this act the Secretary of the Interior shall open to homestead settlement, as herein provided, the lands on all the reservations, or portions of reservations, which have been ceded to the United States by the Chippewa Indians in Minnesota, including the four reservations last aforesaid, which have been examined and found to be agricultural lands, and shall immediately proceed to have examined, as herein provided, the remaining lands, and shall without delay open to homestead settlement those found to be agricultural lands: Provided, That on the four reservations last aforesaid, where agricultural lands are included within or contiguous to forestry lands and are, in the opinion of the Forester of the Agricultural Department, necessary to the economical administration and protection of the same, said Forester shall, as soon as practicable after the passage of this act as to those lands which have already been examined, and as to the lands not yet examined immediately after the examination and approval of the lists of said lands, of which approval said Forester shall be immediately notified by the Secretary of the Interior, file with the Secretary of the Interior schedules designating according to Government subdivisions said agricultural lands, not to exceed fifteen thousand acres of the lands already examined and not to exceed ten thousand acres of the lands yet to be examined, which said agricultural lands so designated shall not be offered for entry and settlement, but shall become and be a part of the forest reserve hereinbefore created.

"There shall be appointed by the Secretary of the Interior one superintendent and such assistants as he may deem necessary, whose compensation shall be fixed by the Secretary of the Interior, and for the superintendent shall not exceed six dollars per day, and for the assistants shall not exceed four dollar's per day each, while actually employed, and whose duties shall be to supervise the cutting and scaling of the timber sold under the provisions of this act, and to see that the rules and regulations prescribed by the Forester and the Secretary of the Interior are complied with, and generally to perform such services in and about the sale of the pine timber on said lands, and the cutting of the same therefrom, and the care and protection of all timber on said lands, as may be required of them by said Forester and said Secretary.

"The Secretary of the Interior may, in his discretion, authorize the purchasers of timber hereunder to build on the rivers and lakes on or within said ceded lands, under such rules and regulations as he may deem proper, dams, cofferdams, booms, and to make other river and lake improvements necessary to facilitate logging operations: Pro- 
vided, That the parties building such dams, cofferdams, booms, and making other river and lake improvements shall pay the oflicer whom the Secretary of the Interior shall designate to receive such payments such damages as may be caused on the said ceded lands, such damages to be ascertained and determined in such manner as the Secretary of tlre Interior may direct.

"All the expenses incurred in carrying out the provisions of this act as to the examining and listing of said lands, and the selling, cutting, and scaling of said timber, shall be paid by the Secretary of the Interior out of the proceeds of the sale of said timber: Provided, That no expense arising out of the forestry provision shall be charged to the Indians."

$$
\text { Approved, June 27, } 1902 .
$$

(32 Stat. L., 400.) 


\section{SCHEDULE.}

Description and estimate of water-killed and windfall timber on ceded Chippewa Indian lands in Minnesota.

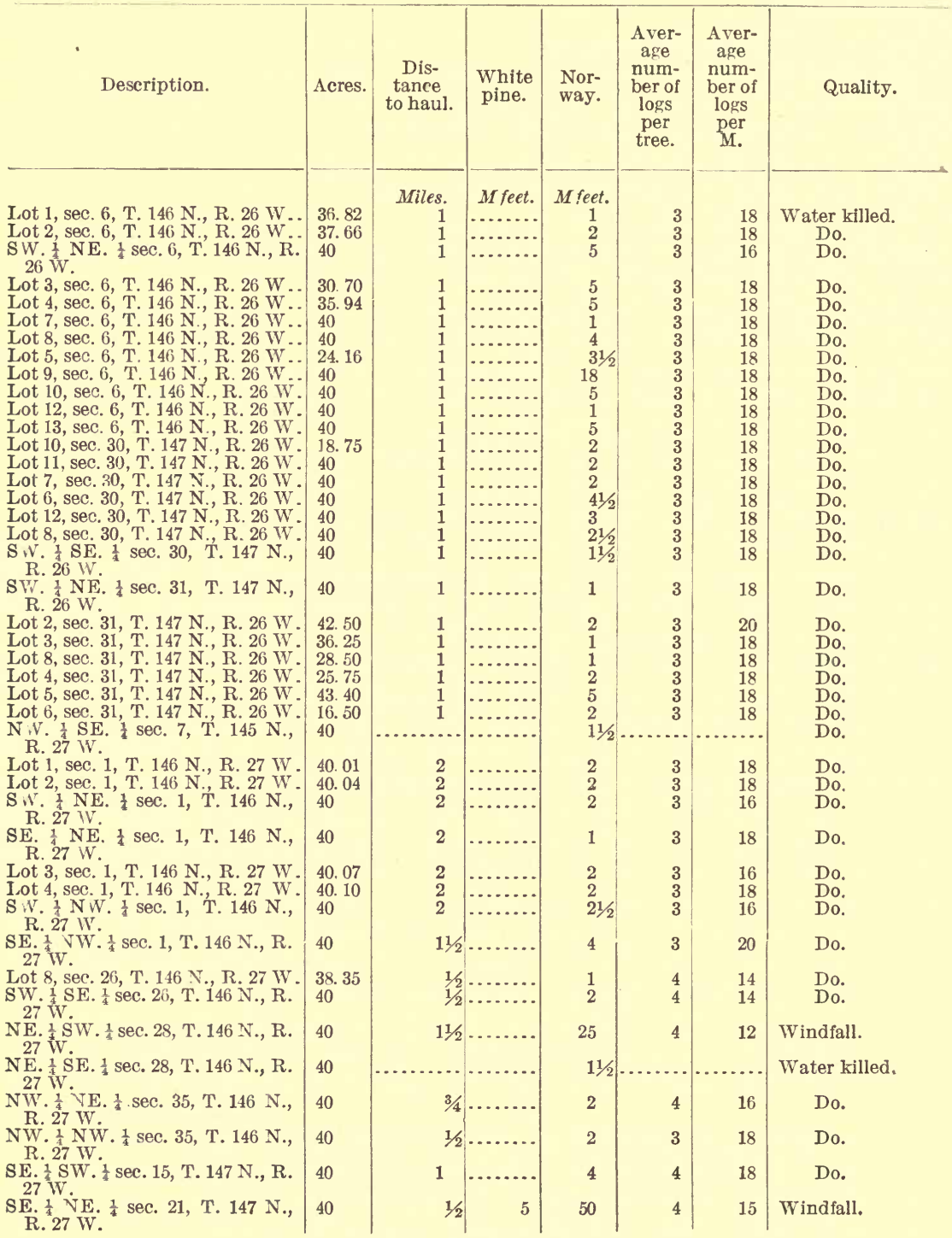



Indian lands in Minnesota-Continued.

\begin{tabular}{|c|c|c|c|c|c|c|c|}
\hline Description. & Acres. & $\begin{array}{l}\text { Dis- } \\
\text { tance } \\
\text { to haul. }\end{array}$ & $\begin{array}{l}\text { White } \\
\text { plne. }\end{array}$ & $\begin{array}{l}\text { Nor- } \\
\text { way. }\end{array}$ & $\begin{array}{c}\text { Aver- } \\
\text { age } \\
\text { num- } \\
\text { ber of } \\
\text { logs } \\
\text { per } \\
\text { tree. }\end{array}$ & $\begin{array}{c}\text { Aver- } \\
\text { age } \\
\text { num- } \\
\text { ber of } \\
\text { logs } \\
\text { per } \\
\text { M. }\end{array}$ & Quallty. \\
\hline E. $\frac{1}{2}$ SE. $\frac{1}{4}$ sec. 21, T. 147 N., & 40 & $\begin{array}{l}\text { Miles. } \\
\text { On lake. }\end{array}$ & & $\underset{5}{M \text { feet. }}$ & 3 & 14 & Windfall. \\
\hline $\begin{array}{l}\text { SW. } \\
\text { R. } 27 \text { W. }\end{array}$ & 40 & & & 50 & 4 & 12 & Do. \\
\hline $\begin{array}{l}\text { Lot } 3 \text {, sec. } 21, \text { T. } 147 \text { N., R. } 27 \text { W. } \\
\text { SW. } \\
\text { R. } 27 \text { W. }\end{array}$ & $\begin{array}{l}32.50 \\
40\end{array}$ & On lake. & & $\begin{array}{r}8 \\
30\end{array}$ & $\begin{array}{l}3 \\
4\end{array}$ & $\begin{array}{l}12 \\
12\end{array}$ & $\begin{array}{l}\text { Do. } \\
\text { Do. }\end{array}$ \\
\hline SE. $\frac{1}{1}$ NE. $\frac{1}{4}$ sec. 22, T. 147 N., & 40 & & & 150 & 4 & 15 & Do. \\
\hline $\begin{array}{l}\text { NW. } \frac{1}{1} \text { NW. } \frac{1}{4} \text { sec. } 22 \text {, T. } 147 \text { N., } \\
\text { R. } 27 \text { W. }\end{array}$ & 40 & & & 10 & 3 & 20 & Do. \\
\hline $\begin{array}{l}\text { SW. } \\
\text { R. } 27 \text { WW. }\end{array}$ & & $1 / 2$ & & 5 & 4 & 15 & Windfall poor. \\
\hline $\begin{array}{l}\text { SE. } \\
\text { R. } 27 \mathrm{WW} .\end{array}$ & 40 & $1 / 4$ & & 20 & 4 & 12 & Windfall good. \\
\hline $\begin{array}{l}\text { NE. } \frac{1}{2} \text { SW. } \frac{1}{2} \text { sec. } 22, \text { T. } 147 \text { N., } \\
\text { R. } 27 \text { W. }\end{array}$ & 40 & On lake. & & 4 & 3 & 25 & Windfall poor. \\
\hline $\begin{array}{l}\text { NW. } \frac{1}{2} \text { SW. } \frac{1}{1} \text { sec. } 22, \text { T. } 147 \text { N., } \\
\text { R. } 27 \text { W. }\end{array}$ & 40 & $1 / 4$ & & 8 & 3 & 15 & Windfall. \\
\hline 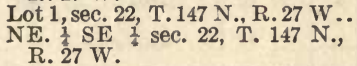 & $\begin{array}{l}31.40 \\
40\end{array}$ & On lake. & & $\begin{array}{r}7 \\
75\end{array}$ & $\begin{array}{l}3 \\
4\end{array}$ & $\begin{array}{l}12 \\
12\end{array}$ & $\begin{array}{l}\text { Do. } \\
\text { Windfall good. }\end{array}$ \\
\hline $\begin{array}{l}\text { NW. } \frac{1}{1} \text { SE. } \frac{1}{4} \text { sec. } 22, \text { T. } 147 \text { N., } \\
\text { R. } 27 \text { W. }\end{array}$ & 40 & On lake. & & 2 & 2 & 25 & Windfall. \\
\hline $\begin{array}{l}\text { SE. } \frac{1}{1} \text { SE. } \frac{1}{4} \text { sec. } 22, \text { T. } 147 \text { N., } \\
\text { R. } 27 \text { W. }\end{array}$ & 40 & $1 / 4$ & & 100 & 4 & 12 & Windfall good. \\
\hline $\begin{array}{l}\text { SE. NE. } \\
\text { R. } 27 \text { W. }\end{array}$ & 40 & $18 / 4$ & & 10 & 4 & 15 & Down from fire. \\
\hline 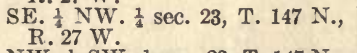 & 40 & 1 & & 5 & 4 & 12 & Windfall. \\
\hline $\begin{array}{l}\text { NW. } \\
\text { R. } 27 \text { WW. }\end{array}$ & 40 & & & 2 & 4 & 12 & Windfall good. \\
\hline $\begin{array}{l}\text { SW. } \\
\text { R. } 27 \text { W. }\end{array}$ & 40 & $1 / 4$ & & 2 & 4 & 12 & Do. \\
\hline $\begin{array}{l}\text { NE. } \frac{1}{1} \text { SE. } \frac{1}{4} \text { sec. } 23, \text { T. } 147 \text { N., } \\
\text { R. } 27 \text { W. }\end{array}$ & 40 & $1 / 2$ & & 3 & 3 & 15 & Down from fire. \\
\hline $\begin{array}{l}\text { SE. SE. } \\
\text { R. } 27 \text { W. }\end{array}$ & 40 & $11 / 2$ & & 6 & 3 & 15 & $\begin{array}{l}\text { Windfall and wa- } \\
\text { ter killed. }\end{array}$ \\
\hline $\begin{array}{l}\text { SW. } \\
\text { R. } 27 \text { W. }\end{array}$ & 40 & $/ 2$ & & 3 & 4 & 15 & Down from fire. \\
\hline $\begin{array}{l}\text { NW. } \frac{1}{4} \text { SW. } \frac{1}{4} \text { sec. } 24, \text { T. } 147 \text { N., } \\
\text { R. } 27 \text { W. }\end{array}$ & 40 & 1 & & 6 & 4 & 25 & Do. \\
\hline $\begin{array}{l}\text { SW. } \\
\text { R. } 27 \mathrm{WW} .\end{array}$ & 40 & 1 & & 7 & 4 & 25 & $\begin{array}{l}\text { Down from fire and } \\
\text { water killed. }\end{array}$ \\
\hline $\begin{array}{l}\text { SE. } \\
\text { R. } 27 \text { W. }\end{array}$ & 40 & 1 & & 1 & 4 & 20 & Very poor. \\
\hline $\begin{array}{l}\text { SE. } \frac{1}{2} \text { NE. } \frac{1}{4} \text { sec. } 25 \text {, T. } 147 \text { N., } \\
\text { R. } 27 \mathrm{~W} .\end{array}$ & 40 & & & 3 & 4 & 22 & Dead and down. \\
\hline $\begin{array}{l}\text { NE. } 1 \text { NW. } 1 \text { sec. } 25 \text {, T. } 147 \text { N., } \\
\text { R. } 27 \mathrm{~W} \text {. }\end{array}$ & 40 & & & 6 & 4 & 20 & Do. \\
\hline $\begin{array}{l}\text { NW. }{ }^{1} \text { NW. } \frac{1}{4} \text { sec. } 25, \text { T. } 147 \text { N., } \\
\text { R. } 27 \text { W. }\end{array}$ & 40 & & & 3 & 3 & 20 & Water killed. \\
\hline SW. NW. $\frac{1}{4}$ sec. 25, T. 147 N., & 40 & & & 7 & $31 / 2$ & 20 & $\begin{array}{l}\text { Water killed and } \\
\text { dead and down. }\end{array}$ \\
\hline $\begin{array}{l}\text { SE. } \frac{1}{2} \text { NW } \\
\text { R. } 27 \text { W. }\end{array}$ & 40 & & & 6 & 3 & 18 & Do. \\
\hline $\begin{array}{l}\text { NE. } \frac{1}{2} \text { SW } \frac{1}{4} \text { sec. } 25, \text { T. } 147 \text { N., } \\
\text { R. } 27 \text { W. }\end{array}$ & 40 & & & 5 & $31 / 2$ & 16 & Do. \\
\hline $\begin{array}{l}\text { NE. } 1 \text { SE. } \frac{1}{1} \text { sec. } 25, \text { T. } 147 \text { N., } \\
\text { R. } 27 \text { W. }\end{array}$ & 40 & $1 / 4$ & & 2 & 4 & 16 & Dead and down. \\
\hline $\begin{array}{l}\text { NW. } \frac{1}{1} \text { SE. } \frac{1}{4} \text { sec. } 25, \text { T. } 147 \text { N., } \\
\text { R. } 27 \text { W. }\end{array}$ & 40 & & & 61 & 4 & 18 & $\begin{array}{l}\text { Dead and down } \\
\text { and water killed. }\end{array}$ \\
\hline $\begin{array}{l}\text { NE. NE. sec. } 26, \text { T. } 147 \text { N., } \\
\text { R. } 27 \text { W. }\end{array}$ & 40 & & & 1 & 4 & 15 & Water killed. \\
\hline $\begin{array}{l}\text { SE. }+ \text { NE. sec. } 26, \text { T. } 147 \text { N., } \\
\text { R. } 27 \text { W. }\end{array}$ & 40 & & & 1 & 4 & 16 & Do. \\
\hline $\begin{array}{l}\text { NW. SE. } \frac{1}{4} \text { sec. } 26, \text { T. } 147 \text { N., } \\
\text { R. } 27 \text { W. }\end{array}$ & 40 & & & 3 & 4 & 15 & $\begin{array}{l}\text { Windfall and water } \\
\text { killed. }\end{array}$ \\
\hline $\begin{array}{l}\text { NW. } \frac{1}{2} \text { W. } \frac{1}{3} \text { sec. } 26, \text { T. } 147 \text { N., } \\
\text { R. } 27 \text { W. }\end{array}$ & 40 & & & 5 & 2 & 20 & Water killed. \\
\hline $\begin{array}{l}\text { SE. } \\
\text { R. } 27 \text { W. }\end{array}$ & 40 & & & 6 & 3 & 20 & Do. \\
\hline Lot 2, sec. 27, T. 147 N., R. 27 W. & 32 & & & 12 & & 15 & Do. \\
\hline
\end{tabular}


Description and estimate of watcr-killed and windfall timber on ceded Chippcwa Indian lands in Minnesota-Contiuued.

\begin{tabular}{|c|c|c|c|c|c|c|c|}
\hline Description. & Acres. & $\begin{array}{c}\text { Dis- } \\
\text { tance } \\
\text { to haul. }\end{array}$ & $\begin{array}{l}\text { White } \\
\text { pine. }\end{array}$ & $\begin{array}{l}\text { Nor- } \\
\text { way. }\end{array}$ & $\begin{array}{l}\text { Aver- } \\
\text { age } \\
\text { num- } \\
\text { ber of } \\
\text { logs } \\
\text { per } \\
\text { iree. }\end{array}$ & $\begin{array}{c}\text { Aver- } \\
\text { age } \\
\text { num- } \\
\text { ber of } \\
\text { logs } \\
\text { per } \\
\text { M. }\end{array}$ & Quality. \\
\hline $\begin{array}{l}\text { Lot } 1 \text {, sec. } 28, \text { T. } 147 \text { N., R. } 27 \text { W. } \\
\text { Lot 2, sec. } 28, \text { T. } 147 \text { N., R. } 27 \text { W } \\
\text { NW. }\end{array}$ & $\begin{array}{l}49 \\
39.5 n \\
40\end{array}$ & $\begin{array}{r}\text { Miles. } \\
1 / 4 \\
1 / 4 \\
1 / 2\end{array}$ & M feet. & $\begin{array}{c}M \text { feet. } \\
12 \\
6 \\
8\end{array}$ & $\begin{array}{l}3 \\
3 \\
31 / 2\end{array}$ & $\begin{array}{l}12 \\
15 \\
15\end{array}$ & $\begin{array}{l}\text { Windfalls. } \\
\text { Do } \\
\text { Water killed. }\end{array}$ \\
\hline $\begin{array}{l}\text { R. } 27 \mathrm{~W} . \\
\text { SW. } \\
\text { R. } 27 \mathrm{WE} . \frac{1}{4} \mathrm{sec} .35, \text { T. } 147 \mathrm{~N} .\end{array}$ & 40 & $1 / 4$ & & 2 & 3 & 14 & Do. \\
\hline $\begin{array}{l}\text { Lot } 2 \text {, sec. } 3 \text { H, T. } 147 \text { N., R. } 27 \text { W.. } \\
\text { Lot 1, sec. } 36, \text { T. } 147 \text { N., R. } 27 \text { W. } \\
\text { NW. + NW. } 1 \text { sec. } 36, \text { T. } 147 \text { N., } \\
\text { R. } 27 \text { W. }\end{array}$ & \begin{tabular}{l|}
24 \\
39.65 \\
40
\end{tabular} & $1 / 2$ & & $\begin{array}{r}14 \\
2 \\
1\end{array}$ & $\begin{array}{l}3 \\
3 \\
3\end{array}$ & & $\begin{array}{l}\text { Do. } \\
\text { Do. } \\
\text { Do. }\end{array}$ \\
\hline $\begin{array}{l}\text { SW. SW. } 1 \text { sec. } 36, \text { T. } 147 \text { N., } \\
\text { R. } 27 \mathrm{~W} .\end{array}$ & 40 & $1 / 2$ & & 5 & 3 & 14 & Do. \\
\hline 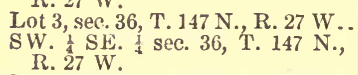 & $\begin{array}{l}47.25 \\
40\end{array}$ & 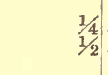 & & $\begin{array}{l}6 \\
1\end{array}$ & $\begin{array}{l}3 \\
3\end{array}$ & $\begin{array}{l}18 \\
16\end{array}$ & $\begin{array}{l}\text { Do. } \\
\text { Do. }\end{array}$ \\
\hline $\begin{array}{l}\text { Iot } 4 \text {, sec. } 36, \text { T. } 147 \text { N., R. } 27 \text { W.. } \\
\text { NE. } 1 \mathrm{SE} \text {. } \\
\text { R. } 28 \mathrm{~W} \text {. }\end{array}$ & $\begin{array}{l}40.30 \\
40\end{array}$ & $1 / 4$ & 10 & $\begin{array}{r}2 \\
25\end{array}$ & $\begin{array}{l}3 \\
4\end{array}$ & $\begin{array}{l}18 \\
12\end{array}$ & $\begin{array}{l}\text { Do. } \\
\text { Dead and down. }\end{array}$ \\
\hline 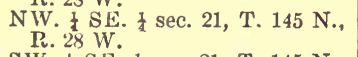 & 40 & $1 / 4$ & 15 & 12 & 4 & 12 & Do. \\
\hline $\begin{array}{l}\text { SW. SE. } \frac{1}{1} \text { sec. } 21, \text { T. } 145 \text { N., } \\
\text { R. } 28 \text { W. }\end{array}$ & 40 & $\ldots$ & 3 & 1 & $\ldots$ & 12 & Do. \\
\hline $\begin{array}{l}\text { SE. } 1 \text { SE. } \frac{1}{4} \text { sec. } 21 \text {, T. } 145 \text { N., } \\
\text { R. } 28 \text { W. }\end{array}$ & 40 & $1 / 2$ & 15 & 10 & 4 & 12 & Do. \\
\hline $\begin{array}{l}\text { NW. } \\
\text { R. } 28 \text { WW. } \frac{1}{4} \text { sec. } 27, \text { T. } 145 \text { N., }\end{array}$ & 40 & $1 / 2$ & & 8 & 3 & 14 & Do. \\
\hline $\begin{array}{l}\text { NE. } 1 \text { NE. } \frac{1}{1} \text { sec. } 28 \text {, T. } 145 \text { N., } \\
\text { R. } 28 \mathrm{~W} \text {. }\end{array}$ & 40 & $1 / 2$ & 4 & 8 & & 14 & Do. \\
\hline $\begin{array}{l}\text { NW. } \frac{1}{4} \text { NE. } \frac{1}{1} \mathrm{sec} .28, \text { T. } 14.5 \text { N., } \\
\text { R. } 2.8 \text {. }\end{array}$ & 40 & 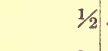 & & 10 & .. & 14 & Do. \\
\hline $\begin{array}{l}\text { SW. NE. } \\
\text { R. } 31 \mathrm{~W} \text {. }\end{array}$ & 40 & $3 / 2$ & & 40 & 4 & 9 & Do. \\
\hline $\begin{array}{l}\text { SE. NE. } \\
\text { R. } 31 \text { sec. } 23, \text { T. } 143 \text { N., }\end{array}$ & 40 & $1 / 2$ & $\cdots$ & $3 \pi$ & 4 & 9 & Do. \\
\hline $\begin{array}{l}\text { Lot } 2 \text {, se.". T. T. } 143 \text { N., R. } 31 \text { W., } \\
\text { SE. NW. Sec. } 23, \text { T. } 143 \text { N., } \\
\text { R. } 31 \mathrm{~W} \text {. }\end{array}$ & $\begin{array}{l}36.90 \\
40\end{array}$ & $\begin{array}{l}1 / 4 \\
1 / 2\end{array}$ & 2 & $\begin{array}{l}15 \\
30\end{array}$ & $\begin{array}{l}4 \\
4\end{array}$ & $\begin{array}{l}9 \\
9\end{array}$ & $\begin{array}{l}\text { Do. } \\
\text { Do. }\end{array}$ \\
\hline $\begin{array}{l}\text { NE. } \frac{1}{3} \mathrm{SW} . \frac{1}{4} \text { sec. } 23 \text { T. } 143 \mathrm{~N} \text {., } \\
\text { R. } 31 \mathrm{~W} \text {. }\end{array}$ & 40 & $1 / 2$ & 19 & 25 & 4 & 9 & Do. \\
\hline 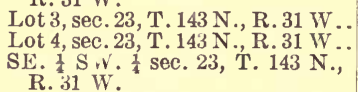 & $\begin{array}{l}33.45 \\
29.05 \\
40\end{array}$ & $\begin{array}{l}1 / 2 \\
1 / 2 \\
1 / 2\end{array}$ & $\begin{array}{r}18 \\
125 \\
67\end{array}$ & $\begin{array}{l}311 / 2 \\
140 \\
112\end{array}$ & $\begin{array}{l}4 \\
5 \\
5\end{array}$ & $\begin{array}{l}9 \\
8 \\
8\end{array}$ & $\begin{array}{l}\text { Do. } \\
\text { Do. } \\
\text { Do. }\end{array}$ \\
\hline $\begin{array}{l}\text { NE. } \\
\text { R. } 31 \mathrm{WE} . \\
\text {. }\end{array}$ & 40 & $1 / 2$ & 60 & 30 & 4 & 9 & Do. \\
\hline $\begin{array}{l}\text { NW. } 1 \text { SE. } \frac{1}{1} \mathrm{sec} .23, \mathrm{~T} .143 \mathrm{~N} . \\
\text { R. } 31 \text { W. }\end{array}$ & 40 & $1 / 2$ & 30 & 35 & 4 & 9 & Do. \\
\hline $\begin{array}{l}\text { SW. } \frac{1}{2 S E} . \frac{1}{4} \text { sec. } 23, \text { T. } 143 \text { N., } \\
\text { R. } 31 \text { W. }\end{array}$ & 40 & $1 / 2$ & 80 & 80 & 5 & 9 & Do. \\
\hline $\begin{array}{l}\text { SE. }+ \text { SE. } \frac{1}{1} \text { sec. } 23, \text { T. } 143 \text { N., } \\
\text { R. } 31 \mathrm{~W} .\end{array}$ & 40 & $1 / 2$ & $751 / 2$ & $941 / 2$ & 4 & 8 & Do. \\
\hline $\begin{array}{l}\text { NW. } \frac{1}{2} \text { SW. } \frac{1}{4} \text { sec. } 24, \text { T. } 143 \text { N., } \\
\text { R. } 31 \text { W. }\end{array}$ & 40 & 1 & 11 & & 5 & 8 & Do. \\
\hline $\begin{array}{l}\text { SW. } \frac{1}{4} \text { SW. } \frac{1}{4} \text { sec. } 24, \text { T. } 143 \text { N., } \\
\text { R. } 31 \text { W. }\end{array}$ & 40 & 1 & 10 & & 5 & 8 & Do. \\
\hline $\begin{array}{l}\text { NW. } \frac{1}{1} \mathrm{NW} .1 \frac{1}{4} \sec .25, \text { T. } 143 \mathrm{~N} . \\
\text { R. } 31 \mathrm{~W} .\end{array}$ & 40 & $1 / 2$ & 10 & 3 & 5 & 7 & Do. \\
\hline $\begin{array}{l}\text { NE. } 1 \text { NE. } \frac{1}{4} \text { sec. } 26, \text { T. } 143 \text { N., } \\
\text { R. } 31 \mathrm{~W} \text {. }\end{array}$ & 40 & $1 / 2$ & 63 & 13 & $41 / 2$ & 7 & Do. \\
\hline $\begin{array}{l}\text { NW. } W_{3}^{1} \text { NE. } \frac{1}{4} \mathrm{sec} .26, \text { T. } 143 \text { N., } \\
\text { R. } 31 \mathrm{~W} .\end{array}$ & 40 & $3 / 4$ & 33 & 17 & $41 / 2$ & 7 & Do. \\
\hline 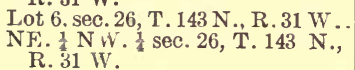 & $\begin{array}{l}45.70 \\
40\end{array}$ & $\begin{array}{l}1 / 2 \\
1 / 2\end{array}$ & $\begin{array}{l}16 \\
15\end{array}$ & $\begin{array}{l}33 \\
10\end{array}$ & $\begin{array}{l}4 \\
41 / 2\end{array}$ & $\begin{array}{l}9 \\
7\end{array}$ & $\begin{array}{l}\text { Do. } \\
\text { Do. }\end{array}$ \\
\hline 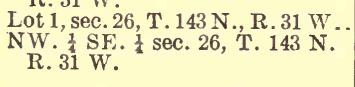 & $\begin{array}{l}26.70 \\
40\end{array}$ & $\begin{array}{l}1 / 4 \\
1 / 2\end{array}$ & $\begin{array}{l}50 \\
16\end{array}$ & $\begin{array}{l}50 \\
33\end{array}$ & $4 \frac{41 / 2}{4}$ & $\begin{array}{l}7 \\
9\end{array}$ & $\begin{array}{l}\text { Do. } \\
\text { Do. }\end{array}$ \\
\hline
\end{tabular}


RECAPITULATION.

Sec. 6, T. 146 N., R. 26 W

Sec. 30 , T. 147 N., R. 26 W

Sec. 31 , T. 147 N., R. 26 W

Sec. 7, T. 145 N., R. $27 \mathrm{~W}$

Sec. 1, T. 146 N., R. 27 W

Sec. 26, T. 146 N., R. 27 W

Sec. 28 , T. 146 N., R. 27 W

Sec. 35, T. 146 N., R. 27 W

Sec. 15, T. 147 N., R. 27 W

Sec. 21, T. 147 N., R. 27 W

Sec. 22 , T. 147 N., R. 27 W

Sec. 23. T. 147 N., R. 27 W

Sec. 24, T. 147 N., R. 27 W

Sec. 25, T. 147 N., R. 27 W

Sec. 26, T. 147 N., R. 27 W

Sec. 27, T. 147 N.. R. 27 W

Sec. 28, T. 147 N., R. 27 W

Sec. 35 , T. 147 N., R. 27 W

Sec. 36, T. 147 N., R. 27 W

Sec. 21 , T. 145 N., R. 28 W

Sec. 27, T. 145 N., R. 28 W

Sec. 28 , T. 145 N., R. 28 W

Sec. 23, T. 143 N., R. 31 W

Sec. 24, T. 143 N., R. 31 W

Sec. 25, T. 143 N., R. 31 W

Sec. 26, T. 143 N., R. 31 W

Total.

\begin{tabular}{|c|c|c|}
\hline Acres. & White pine. & Norway. \\
\hline $\begin{array}{c}445.28 \\
258.75 \\
232.90 \\
40 \\
320.22 \\
78.35 \\
80 \\
80 \\
40 \\
152.50 \\
431.40 \\
240 \\
160 \\
320 \\
200 \\
32 \\
88.50 \\
80 \\
271.20 \\
160 \\
40 \\
80 \\
480 \\
80 \\
40 \\
232.40\end{array}$ &  & $\begin{array}{c}\text { Mfeet. } \\
551 / 2 \\
171 / 2 \\
14 \\
11 / 2 \\
171 / 2 \\
3 \\
261 / 2 \\
4 \\
4 \\
113 \\
411 \\
28 \\
17 \\
381 / 2 \\
16 \\
12 \\
18 \\
10 \\
31 \\
48 \\
8 \\
18 \\
661 \\
\ldots . . \\
3 \\
156\end{array}$ \\
\hline $4,663.50$ & $7551 / 2$ & 1,732 \\
\hline
\end{tabular}

\section{Departarent of the INTERIor,} General Land Office,

Washington, D. C., November 16, 1909.

I respectfully recommend approval of the foregoing schedule of merchantable down and water-killed timber on lands classified as "pine" lands in accordance with the provisions of the act of June 27, 1902 (32 Stat. L., 400).

Fred Dennett, Commissioner.

Department of the Interior, November 16, 1909.

The foregoing schedule is hereby approved.

R. A. Ballinger, Secretary. 




(1) 13

(5)

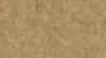




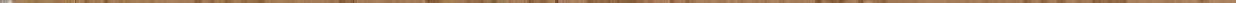




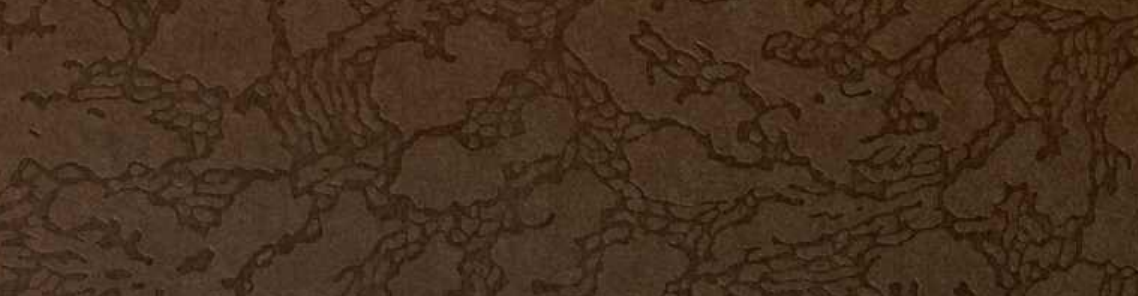

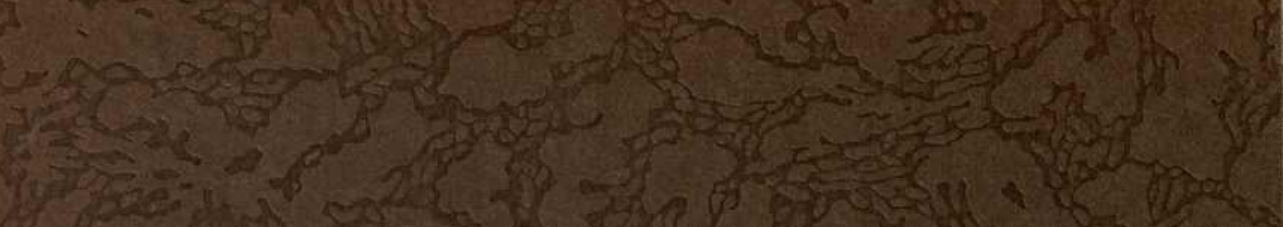

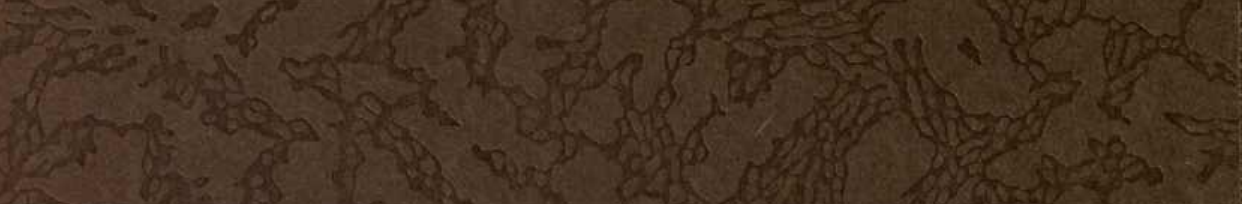

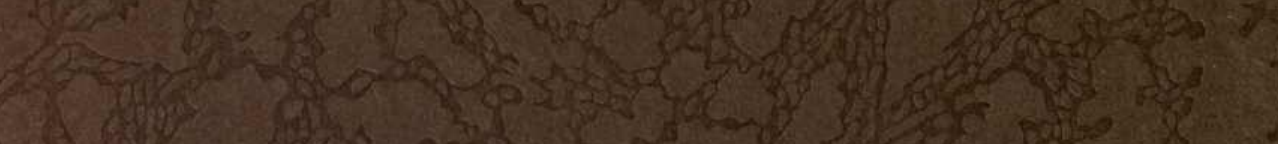

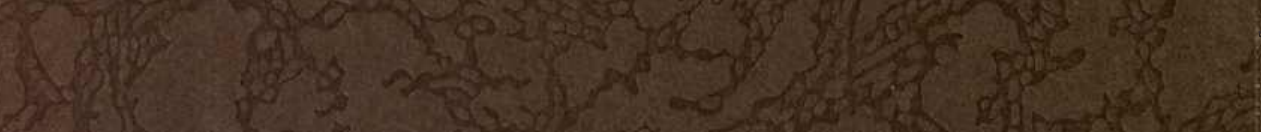

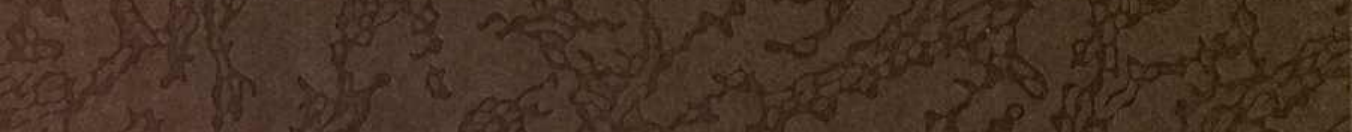

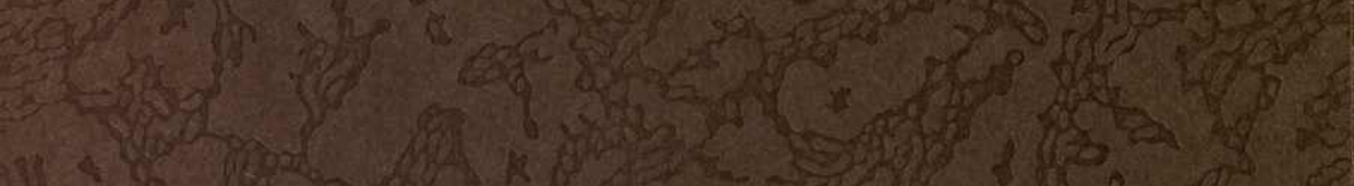

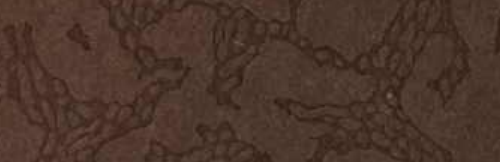

2)





5xiteo

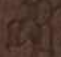
(150

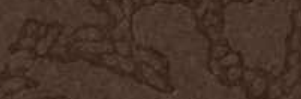

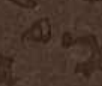

arthe 